\title{
Production of Extracellular Pectinase by Bacillus Cereus Isolated From Market Solid Waste
}

\author{
Elangovan Namasivayam¹, John Ravindar. D1, Mariappan K², Akil jiji², Mukash Kumar² and Richard L Jayaraj ${ }^{1}$
}

${ }^{1}$ Periyar University, Salem, Tamil Nadu, India

${ }^{2} \mathrm{CAS}$ in Botany, University of Madras, Chennai-600025, India

\begin{abstract}
Pectin is a major component of primary cell wall of all land plants and encompasses a range of galacturonic acid rich polysaccharides. Pectinase or pectinolytic enzyme, hydrolyzes pectic substance, they have a share of $25 \%$ in the global sales of food enzymes. Production of this enzyme is affected by the nature of solid substrate, level of moisture content, presence or absence of carbon, nitrogen, minerals and vitamin supplements. Maximum enzyme production $(44 \mathrm{U} / \mathrm{ml})$ is achieved when temperature is around $37^{\circ} \mathrm{C}, \mathrm{pH} .8 .5$, pectin as a carbon source, yeast extract as a nitrogen source and incubation time is 36 hours. In addition to this, wheat bran acts as a better agro substrate and Magnesium chloride as supplement for better production of pectinase. The sequence analysis of 165 rDNA of the isolated organism was much similar when compared with gyrase B gene (gyrB) of Bacillus cereus. Pectinolytic enzyme is of significant importance in the application of apple juice industry in the current biotechnological era.
\end{abstract}

\section{Introduction}

Enzymes are biocatalysts which are synthesized by living cells. It is also defined as the catalyst that increases a velocity or rate of a chemical reaction. Many bacteria, fungi and higher plants are known to produce pectinolytic enzyme called pectinase, that breakdown pectin, a polysaccharide substrate that is found in the cell wall of plants. One of the most important and widely used commercial pectinase is polygalacturonase (PGA). Pectin was first isolated and described by Henri Braconnot (1825). Pectin is the jelly like matrix structural polysaccharide found in primary cell wall and middle lamella of fruits and vegetables [1]. The pectinases are required for extraction and clarification of fruit juices and wines, extraction of oils, flavors and pigments from plant materials, preparation of cellulose fibers for linen, jute and hemp manufacture, coffee and tea fermentations and novel applications in the production of oligogalacturonides as functional food components [2]. Bacillus cereus is an endemic, soil dwelling, Gram-positive, rod-shaped, beta hemolytic bacterium. Bacillus sp was discovered by Cohn and Koch in the $19^{\text {th }}$ century. The Bacillus cereus group is composed of $B$. anthracis, B. cereus, B. mycoides, $B$. pseudomycoides, $B$. thuringiensis and $B$. weihenstephanensis $[3,4]$. The capacity of selected Bacillus sp to produce and secrete large quantities (20-25 g/L) of extracellular enzymes has placed them among the most important industrial enzyme producers [5]. Pectic substances are widely distributed in fruits and vegetables (10-30\% in turnips peels of orange and in pulps of tomato, pineapple and lemon); hence they form important natural substrates for pectinases. Pectinases are mainly used for increasing filtration efficiency and clarification of fruit juices.

\section{Material and Methods}

\section{Materials}

Nutrient Agar Medium (NA), Luria Bertani Medium (LB), Pectate Agar Medium (PA), Growth medium (composition: Peptone - 3g, Yeast extract - 0.5g, $\mathrm{KH}_{2} \mathrm{PO}_{4}-0.15 \mathrm{~g}, \mathrm{CaCl}_{2}-0.001 \mathrm{~g}$, Pectin - 0.5g, $\mathrm{Na}_{2} \mathrm{CO}_{3}$ - $0.5 \mathrm{~g}$ at $\mathrm{pH}-8.0$ ) were the media used. The materials used were Agar, Cetyltrimethyl Ammonium Bromide (CTAB), Thiobarbituric Acid (TBA), Tris $\mathrm{HCl}$, Polygalacturonic acid (PGA), $\mathrm{NaOH}$, Bradford reagent, Glucose, Lactose, Sucrose, Maltose, Tryptone, Potassium nitrate and Ammonium sulphate, SDS, Triton-X 100, EDTA, zinc sulphate, Magnesium chloride, Sugarcane baggase, Orange baggase, Rice bran, Wheat bran, Green gram peel, $100 \mathrm{mM}$ glycine buffer
$\mathrm{pH}$ 10.0, $1.5 \mathrm{mM} \mathrm{CaCl}$, 0.05\% Ruthenium red (Sigma), 1\% agarose, Sodium Dodecyl Sulphate PolyAcrylamide Gel Electrophoresis (SDSPAGE) reagents and Apple. The sample was collected from the market solid waste of Koyambedu market, Chennai, India in a sterile container

\section{Isolation, screening and identification of pectinase producing organism}

The collected sample was serially diluted upto $10^{7}$ dilutions. It was plated on NA medium and incubated at $37^{\circ} \mathrm{C}$ for 24 hours. The isolated pure strains were screened for extra cellular pectinase production using PA Medium containing PGA as a substrate [6]. The substrate utilized zone around the colony was observed using 3.3\% CTAB solution overlaid on the medium and incubated for $10 \mathrm{~min}$. The positive strain that produced maximum pectinase enzyme was selected and identified by biochemical and morphological test.

\section{Preparation of inoculum for bacteria and production of} extracellular enzymes

The inoculum for further enzyme modulation and other studies was prepared using LB medium. The pure culture was inoculated and incubated at $37^{\circ} \mathrm{C}$ in a rotary shaker over night. The fresh over night culture was used as an inoculum for enhanced enzyme production. Five $\mathrm{ml}$ of mother inoculum was cultured in $100 \mathrm{ml}$ Nutrient Broth, from that $5 \%$ of inoculum ( $0.5 @ 600$ OD) was transferred aseptically into the Growth medium. The inoculated medium was incubated at $37^{\circ} \mathrm{C}$ for 48 hours by shake flask fermentation method at 200rpm [6].

\section{Determination of extracellular enzyme activity}

Aliquot of $10 \mathrm{ml}$ of the culture suspension was centrifuged at 5000 *Corresponding author: Elangovan Namasivayam, Periyar University, Salem,
Tamil Nadu India, E-mail: elangovannn@gmail.com

Accepted April 01, 2011; Published April 16, 2011

Citation: Namasivayam E, Ravindar JD, Mariappan K, jiji A, Kumar M, et al. (2011) Production of Extracellular Pectinase by Bacillus Cereus Isolated From Market Solid Waste. J Bioanal Biomed 3: 070-075. doi:10.4172/1948-593X.1000046

Copyright: (c) 2011 Namasivayam E, et al. This is an open-access article distributed under the terms of the Creative Commons Attribution License, which permits unrestricted use, distribution, and reproduction in any medium, provided the original author and source are credited. 
rpm for 15 minutes and cell free extract was subjected to enzyme assay. This extract was stored at $4^{\circ} \mathrm{C}$ for further analysis. The plate assay was performed using Pectate Agar plates amended with PGA. The Agar plates were prepared by mixing $0.5 \%$ PGA with $1.5 \%$ agar. A $10 \mathrm{~mm}$ diameter well was cut aseptically with the help of cork borer. The wells were filled with $50 \mu \mathrm{l}$ and $100 \mu \mathrm{l}$ of culture filtrate and incubated at $37^{\circ} \mathrm{C}$ overnight. The substrate utilized zone was observed around the wells for production of pectinase. CTAB solution $(3.3 \%)$ was overlaid on the medium and kept for 10 minutes [7].

Pectinase activity was assayed by the pectin degradation method using TBA [8]. One $\mathrm{ml}$ of crude enzyme added to $1.5 \mathrm{ml}$ of substrate $(1.2 \%$ pectin in $0.2 \mathrm{M}$ Tris $-\mathrm{HCl} \mathrm{pH} 8.5)$ was incubated at $35^{\circ} \mathrm{C}$ for 1 hour. The reaction mixture was terminated by adding $1.5 \mathrm{ml}$ of $(0.01 \mathrm{M})$ TBA and $0.7 \mathrm{ml}$ of $1 \mathrm{~N} \mathrm{HCL}$ and the contents were boiled in water bath for $20 \mathrm{~min}$. Absorbance was measured at $540 \mathrm{~nm}$ in UV- VIS spectrometer (Beckmann).

The total protein content was measured using Bradford method (1976). One $\mathrm{ml}$ of culture filtrate was mixed with $5 \mathrm{ml}$ of Bradford reagent. Absorbance was measured at $595 \mathrm{~nm}$. The protein concentration was determined using BSA as standard.

\section{Effect of ph, temperature and incubation time}

Five percent bacterial inoculum added aseptically to $500 \mathrm{ml}$ of sterile growth medium was incubated at $37^{\circ} \mathrm{C}$ at $150 \mathrm{rpm}$. Twenty $\mathrm{ml}$ of culture was added periodically for 48 hours at every 6 hours intervals. The pectinase activity was determined in the culture filtrate [7].

The effect of $\mathrm{pH}$ on pectinase activity was determined using $5 \%$ inoculum in $100 \mathrm{ml}$ of growth medium at different $\mathrm{pH}(7,7.5,8,8.5,9$, and 9.5) incubated at $37^{\circ} \mathrm{C}$ for 36 hours [9]. The effect of temperature on enzyme activity was determined using the inoculated medium $(\mathrm{pH}$ 8 ) incubated at different temperatures $\left(28^{\circ} \mathrm{C}, 32^{\circ} \mathrm{C}, 37^{\circ} \mathrm{C}, 42^{\circ} \mathrm{C}, 47^{\circ} \mathrm{C}\right.$, and $52^{\circ} \mathrm{C}$ ) for 36 hours[7].

\section{Optimization of different Carbon, Nitrogen Sources and Supplements for pectinase production}

The maximum pectinase activity was estimated using different carbon sources such as Glucose, Lactose, Sucrose, Pectin, PGA and Maltose in inoculated medium, (5\% inoculum in $100 \mathrm{ml}$ of Growth medium, pH-8.5) incubated at $37^{\circ} \mathrm{C}$ for 36 hours. Different nitrogen sources such as Yeast extract, Tryptone, Peptone, Potassium nitrate and Ammonium sulphate were used, similarly different supplements like SDS, Triton-X 100, EDTA, zinc sulphate and Magnesium chloride were used in the medium [10]. The Protein content and Enzyme activity was determined from the culture filtrate collected.

\section{Effect of different crude substrates on pectinase production}

The Growth medium ( $\mathrm{pH}-8.5)$ was prepared and pectin was replaced by different natural products such as Sugarcane baggase, Orange baggase, Rice bran, Wheat bran, and Green gram peel were used as substrates. Five percent bacteria was inoculated in the medium with different substrates and incubated at $37^{\circ} \mathrm{C}$ for 36 hours [11]. The amount of total protein and Enzyme produced from different substrates were estimated using the culture filtrate.

\section{Partial purification of the enzyme}

The culture filtrate was precipitated using $80 \% \mathrm{w} / \mathrm{v}$ of Ammonium sulphate [12]. The precipitated protein was separated by centrifugation around 10,000 rpm for $10 \mathrm{~min}$. The supernatant was discarded and the pellet was dissolved in $2 \mathrm{ml}$ of $0.5 \mathrm{mM}$ Tris- $\mathrm{HCL}$ ( $\mathrm{pH} 8$ ). The precipitated bacterial and fungal protein was transferred to the dialysis membrane, which was pre treated by immersing into warm $0.5 \mathrm{mM}$ Tris-HCL buffer (pH-8) for 10 minutes (Sigma). The pack was suspended freely into a large beaker, which contains around $500 \mathrm{ml}$ of $0.5 \mathrm{mM}$ Tris-HCL buffer ( $\mathrm{pH}-8)$. The buffer was stirred slowly using magnetic stirrer and the entire setup was placed in the cold room for 48 hours. The buffer was changed periodically for every 12 hours for better dialysis. After dialysis the clip from one end of the membrane was removed and the sample was transferred in to the clean plastic vials.

\section{Sds page analysis and zymography of pectinase}

The protein profile and the presence of enzyme were confirmed by SDS PAGE analysis [13]. The SDS-PAGE was performed in $13 \%$ $(\mathrm{w} / \mathrm{v})$ gels and samples were heated for $10 \mathrm{~min}$ at $45^{\circ} \mathrm{C}$ in the sample buffer before loading on wells. After electrophoresis, gels were soaked in $2.5 \%(\mathrm{w} / \mathrm{v})$ Triton X-100 for $30 \mathrm{~min}$, washed in $100 \mathrm{mM}$ glycine buffer $\mathrm{pH} 10.0,1.5 \mathrm{mM} \mathrm{CaCl}_{2}$ for $30 \mathrm{~min}$ and overlaid with $1 \%$ agarose gel containing $0.1 \%$ polygalacturonic acid in the same buffer as above. After $30 \mathrm{~min}$ of incubation at $45^{\circ} \mathrm{C}$, gels were stained with $0.05 \%$ (w/v) Ruthenium red (Sigma) for $10 \mathrm{~min}$ and washed with water until pectatelyase bands became visible [14].

\section{Pcr amplification of 16s rDNA}

The PCR amplification of 16s rDNA was carried out [15], using synthetic primers such as Forward primer: $\left(5^{\prime}\right.$ - ATT GGT GAC ACC GAT CAA ACA - $3^{\prime}$ ) and Reverse primer: (5' - TCA TAC GTA TGG ATG TTA TTC $\left.-3^{\prime}\right)$. The amplified product was run in $1 \%$ agarose gel electrophoresis to confirm the amplification [16].

\section{Determination of pectinase activity on fruits}

The efficiency of extra cellular activity of pectinase enzyme was determined Ranveer et al. [17]. Finely chopped apple pieces of $20 \mathrm{~g}$ weight were added in two beakers. In one beaker $5 \mathrm{ml}$ of partially purified pectinase enzyme and in the other beaker $5 \mathrm{ml}$ of distilled water was added. This setup (after stirring the contents well) was placed inside the boiling water bath at $40^{\circ} \mathrm{C}$ for 20 minutes. With the help of paper coffee filter the juicy watery part was filtered from the beakers. The activity of enzyme on apple was determined. Distilled water with apple pieces acts as control (Figure11).

\section{Results and Discussion}

Seventeen bacterial strains were isolated from the waste samples,

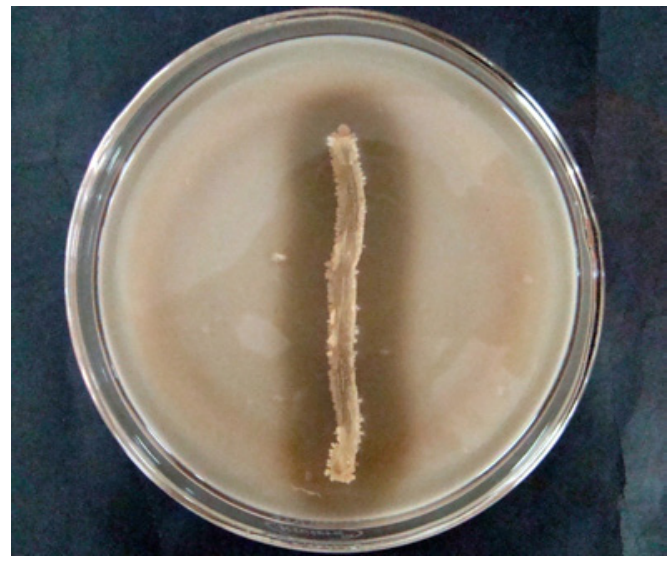

Plate 1: Screening of Bacillus cereus for Pectinases activity in pectate agar plate. 
Citation: Namasivayam E, Ravindar JD, Mariappan K, jiji A, Kumar M, et al. (2011) Production of Extracellular Pectinase by Bacillus Cereus Isolated From Market Solid Waste. J Bioanal Biomed 3: 070-075. doi:10.4172/1948-593X.1000046

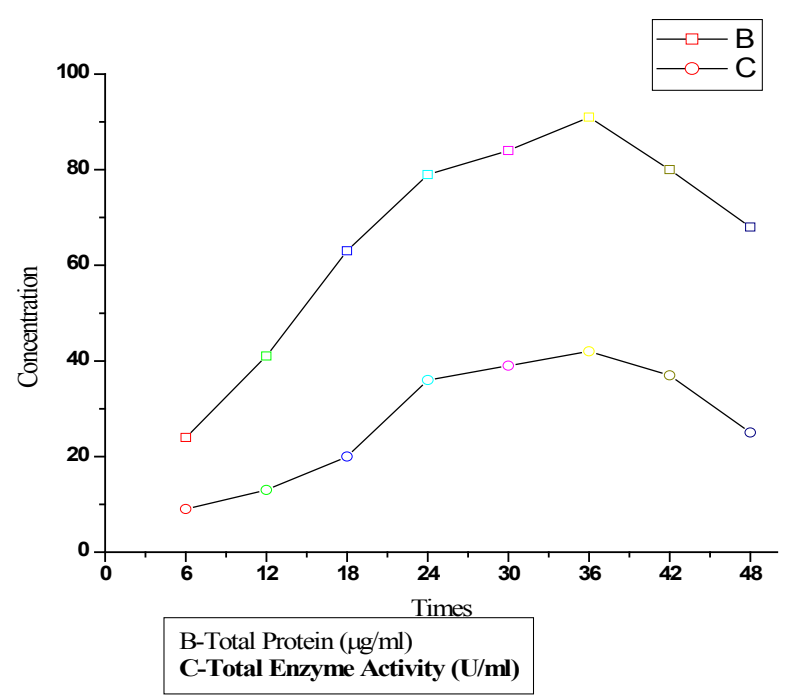

Figure 1: Enzyme Production and Total Protein Content of Bacterial Isolate at Different Incubation Time.

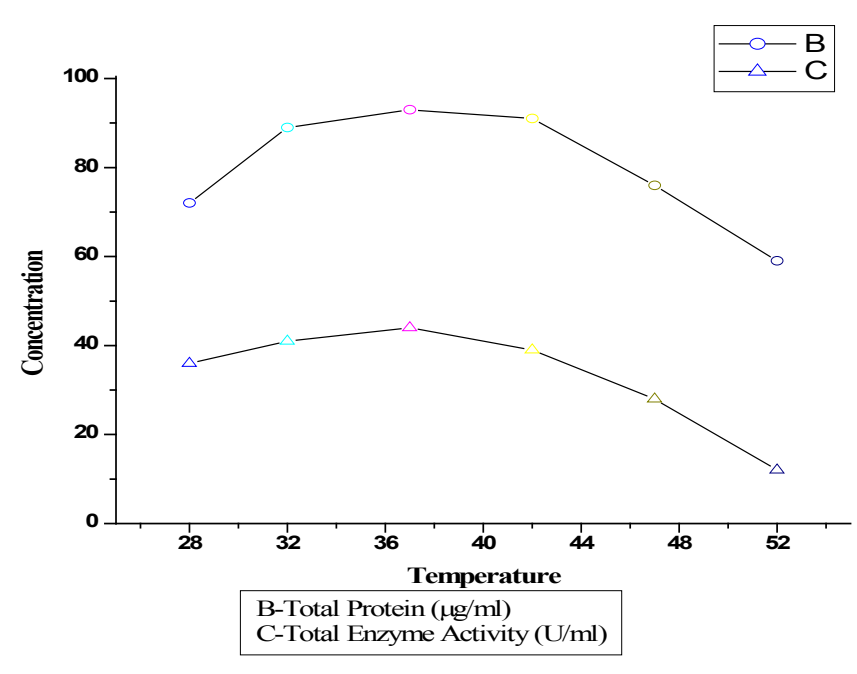

Figure 2: Effect of temperature on total protein and enzyme production by bacterial isolate. The protein concentration is obtained at different temperature $\left(28^{\circ} \mathrm{C}-52^{\circ} \mathrm{C}\right)$. The optimum temperature for total protein content and total enzyme activity is found to be $37^{\circ} \mathrm{C}$.

but later during screening it was found that only 6 bacterial strains showed positive results on pectinase production. Among 6 bacterial strains the better zone forming bacterial strain was identified as Bacillus cereus, by using standard biochemical tests (Plate 1).

\section{Effect of different process parameters for pectinase production}

Time interval on enzyme production: The culture was checked for enzyme activity for 48 hours at every 6 hours interval. The results revealed that there is gradual increase in production from $24^{\text {th }}$ hour and higher production occurred at $36^{\text {th }}$ hour (Figure 1). This shows that bacterial isolate should have maintained its $\log$ phase from $24^{\text {th }}$ hour to $36^{\text {th }}$ hour. Besides, it is believed that the higher production of pectinase has occurred in extreme log phase because even though the $\log$ phase was maintained around $24^{\text {th }}$ to $36^{\text {th }}$ hour, the followed drop of production has indicated that the organism should have entered the stationary phase of growth. This variation of log phase timing is based on the nutrients present in the medium and the cultural condition of the organism. This result correlated with the work of [7] by using some Gram positive bacteria like Bacillus sp.

\section{Temperature and $\mathrm{pH}$}

From our study, it was found that the mesophlic organism has the potential to produce higher amount of pectinase $(44 \mathrm{U} / \mathrm{ml})$ at $37^{\circ} \mathrm{C}$ (Figure 2). This indicates that the optimum temperature for better

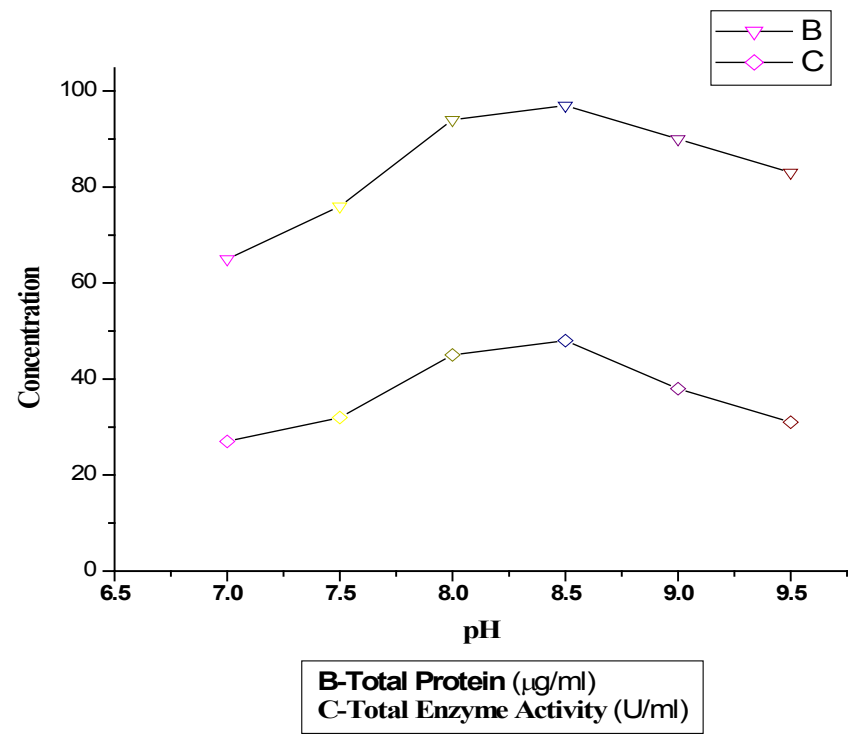

Figure 3: Effect of $\mathrm{pH}$ on total protein and enzyme production of bacterial isolate. The total protein content and total enzyme activity was measured at different $\mathrm{pH}(7.0$ - 9.5). The optimum $\mathrm{pH}$ for higher amount of total protein content and total enzyme activity was found to be 8.5 .

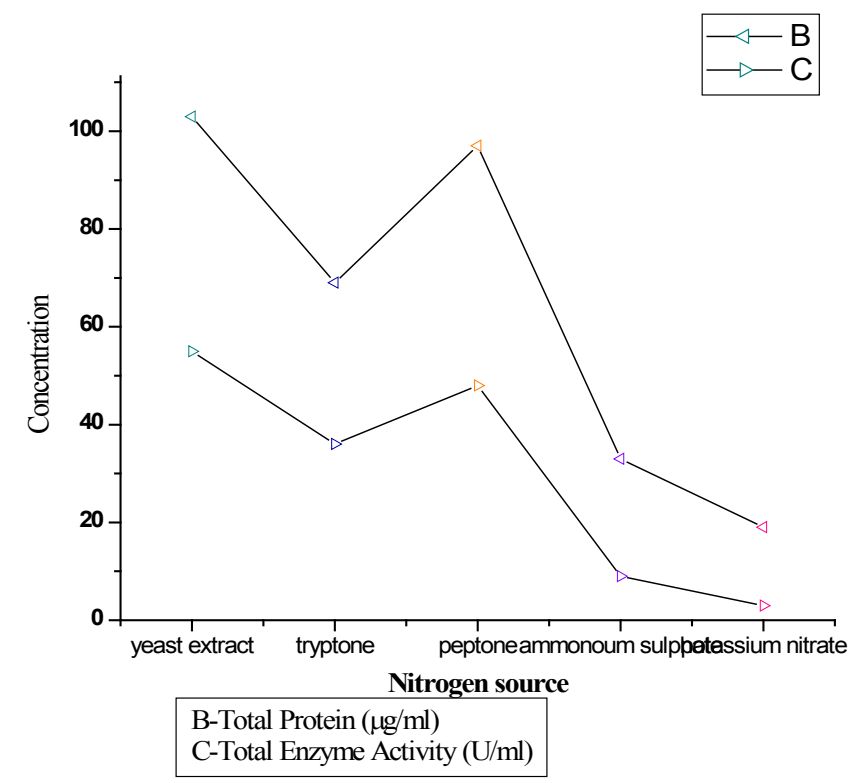

Figure 4: Enzyme production and total protein production on different nitrogen sources. Different nitrogen sources were used. The best nitrogen source for over production of enzyme is found to be yeast extract. 


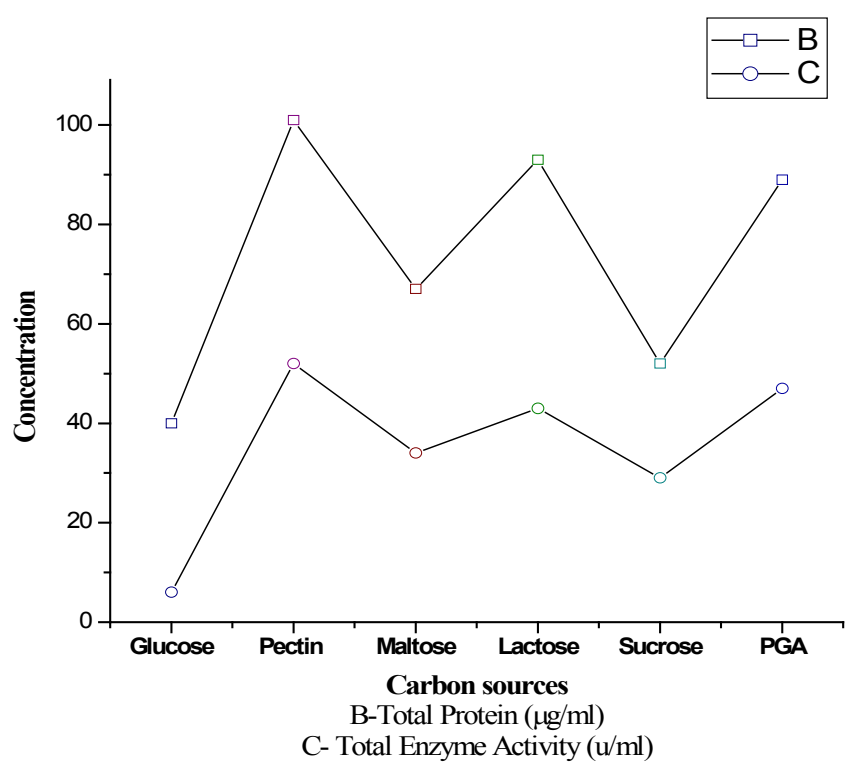

Figure 5: Enzyme production and total protein production on different carbon source. The total protein content and enzyme activity is found to be higher by using.

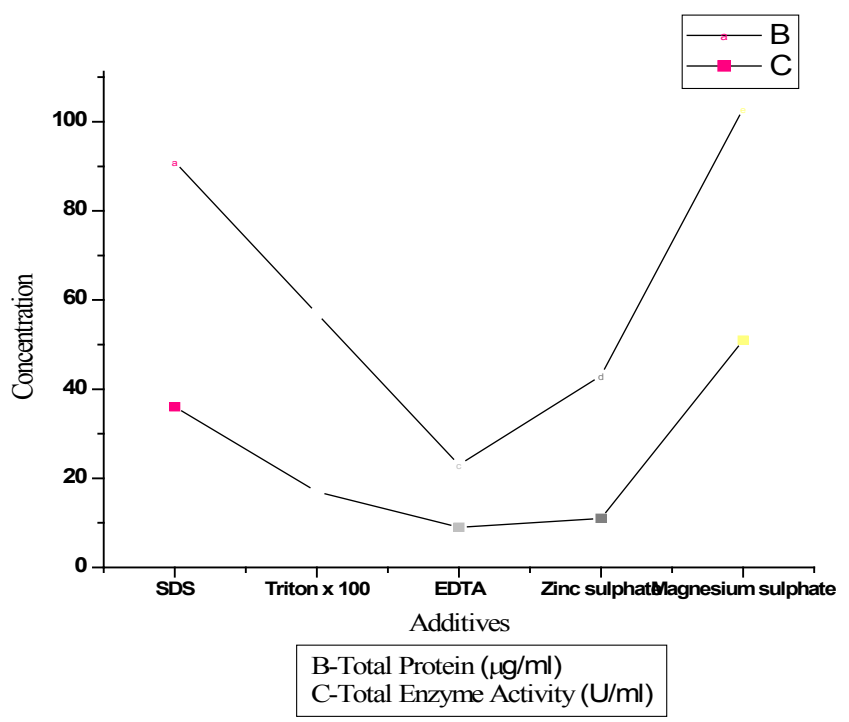

Figure 6: Enzyme and total protein production on different additives.

production of bacterial isolates is $37^{\circ} \mathrm{C}$. Many Bacillus spp. needs 32$37^{\circ} \mathrm{C}$ for better production of pectinase [7].

Similarly the study results revealed that the $\mathrm{pH}$ around 8.5 is optimum for enhanced pectinase production (Figure 3). Most of the Bacillus spp. produce high amount of pectinase between $\mathrm{pH}$ 7-9 [6].

\section{Carbon, nitrogen source and supplements}

Pectin was found to be the right carbon source for bacterial strain for higher production of pectinase (Figure 4) than glucose, due to feed back inhibition. The yeast extract was found to be the best nitrogen source for bacterial isolate to produce pectinase enzyme compared to other nitrogen sources like Ammonium sulphate, tryptone, peptone and potassium nitrate (Figure 5). Magnesium chloride has enhanced the pectinase production in bacteria (Figure 6). This induction may be varying from organism to organism based on the mineral requirement and tolerance against the ionic detergents. Bacillus sp. has produced considerable amount of pectinase from the medium amended with 0.5 ppm of $\mathrm{Ca}^{2+}[7]$.

\section{Crude substrates}

The results revealed that wheat bran was found to enhance pectinase production (Figure 7). Most of the Bacillus spp produce higher quantity of enzyme in wheat bran substrate [12].

\section{SDS PAGE and Zymogram}

The protein profile analyzed by SDS-PAGE showed the presence of multiple protein bands, around molecular weight $30-50 \mathrm{KDa}$, which confirms the presence of pectinase enzyme. This result resembled with the previous work [13], (Figure 8). In zymogram the SDS- PAGE containing pectinase was detected by gel coat. A clear yellow zone appearance in SDS PAGE shows the presence of partially purified pectinase (Figure 9).

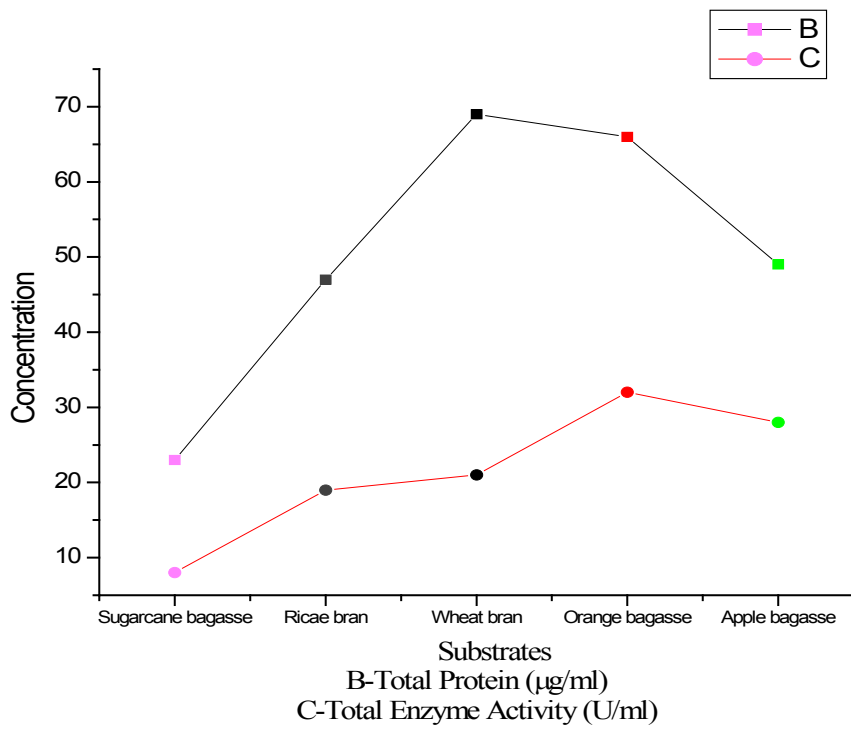

Figure 7: Enzyme and total protein production on different crude substrates.

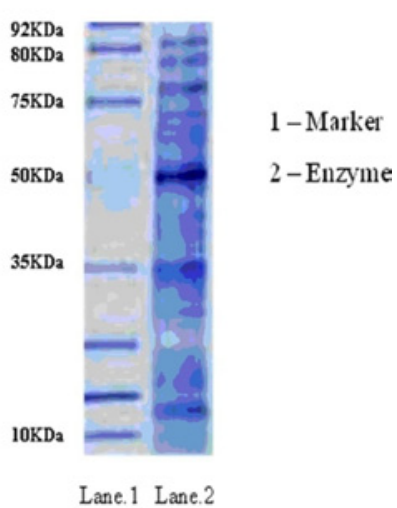

Figure 8: Enzyme profile in SDS- PAGE, lane1 (Marker), lane 2 (Enzyme). 


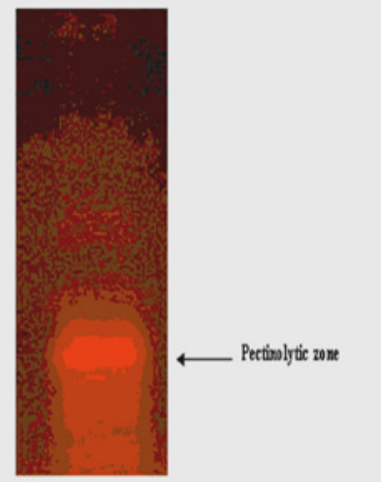

Figure 9: Zymography of pectinases.

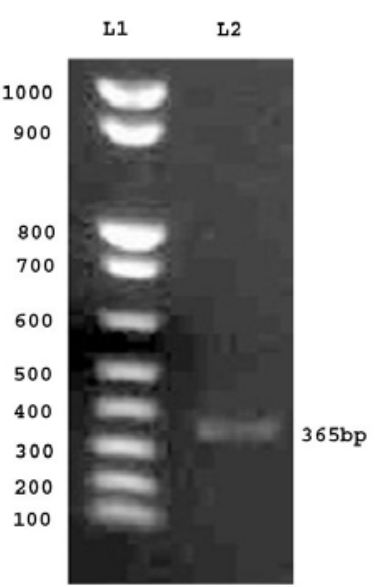

Figure 10: PCR Amplification DNA Lane 1(Marker), Lane 2(Enzyme), 365bp band was observed.

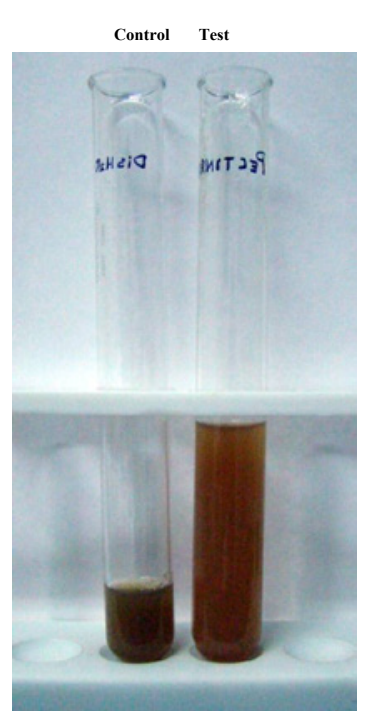

Figure 11: Apple Juice Extraction with Partialy Purified Pectinase.

\section{DNA profile}

The $16 \mathrm{~S}$ rDNA primer was designed for the specific detection of
Bacillus cereus and was tested with genomic DNA of Bacillus cereus. A PCR product of desired size of $365 \mathrm{bp}$ was obtained in reactions containing genomic DNA of the targeted organisms. In DNA sequence analysis of Bacillus cereus, the amplified result was much similar when compared with pectinase producing Bacillus cereus isolated from the market solid waste. Similar work was done in $16 \mathrm{~S}$ rDNA sequence analysis of Bacillus cereus and closely related species using gyrase B gene (gyrB) as a molecular diagnostic marker (Figure 10) [17].

\section{Conclusion}

The pectinase enzyme producing bacterial strain was isolated from market solid waste (Koyambedu market, Chennai, INDIA). The isolated bacterial strain is identified as Bacillus cereus. The production and optimization studies revealed that Bacillus cereus requires $37^{\circ} \mathrm{C}$, $\mathrm{pH} 8.5$, pectin (carbon source), yeast extract (nitrogen source), and 36 hours of incubation time for higher pectinase enzyme production. In addition to this, for enhanced production of pectinase, wheat bran and Magnesium chloride acts as a good agro waste substrate and supplement respectively. The partial purification of pectinase was employed by ammonium sulphate precipitation. The partially purified pectinase was characterized and the protein profile was analyzed in SDS-PAGE and Zymogram by showing the suitable bands. The genomic DNA extraction was performed for further work on $16 \mathrm{~S}$ rDNA Sequencing. The present study clearly indicates that the microbes can be used in fruit juice manufacturing and in allied industry for cost effective production of pectinase. Another important advantage is that the enzyme's properties can be altered by altering the genes responsible through rDNA technology for enhanced production.

\section{References}

1. Ernesto Favela Torres, Tania Volke Sepúlveda, Gustavo Viniegra González (2006) Production of Hydrolytic Depolymerising Pectinases. Food Technol Biotechnol 44: 221-227.

2. Urmila Phutela, Vikram Dhuna, Shobhna Sandhu, Chadha BS (2005) Pectinase and polygalacturonase production by a thermophilic Aspergillus fumigatus isolated from decomposing orange peels. Brazilian Journal of Microbiology 36 63-69.

3. Nakamura L (1998) Bacillus pseudomycoides sp. Nov. Int J of Syst Bacteriol 48: 1031-1035.

4. Nakamura L, Jackson M (1995) Clarification of the Taxonomy of Bacillus mycoides. Int J of Syst Bacteriol 45: 46 - 49.

5. Marcus Schallmey, Ajay Singh, Owen P (2001) Ward Sherlock. Microbia Identification System References. MIDI Inc.

6. Kobayashi T, Koike K, Yoshimatsu T, Higaki N, Suzumatsu A, et al. (1999) Purification and properties of a low-molecular-weight, high-alkaline pectate lyase from an alkaliphilic strain of Bacillus. Basic biotechnology Biochem 63:6572.

7. Soriano M, Diaz P, Pastor FI (2005) Pectinolytic Systems of Two Aerobic Sporogenous Bacterial Strains with High Activity on Pect

in $\quad$ Cur Microbiol 50: 114-118.

8. Gusakov AV, Markov AV, Grishutin SG, Semenova MV, Kondratyeva EG, et al (2002) Viscometric Method for Assaying Of Total Endodepolymerase Activity of Pectinases. Biochemistry (Mosc) 67: 676-682.

9. Patil SR, Dayanand A (2006) Production of pectinase from deseeded sunflower head by Aspergillus niger in submerged and solid-state conditions. Bioresour technol 97: 2054-2058.

10. Natalia Martin, Simone Regina de Souza, Roberto da Silva, Eleni Gomes (2004) Pectinase production by fungal strains in solid-state fermentation using agro-industrial byproduct. Brazilian archives of biology and technology 147: 813-819.

11. Aparna Sharma, Gupta MN (2001) Purification of pectinases by three-phase partitioning, Biotechnology Letters 23: 1625-1627. 
Citation: Namasivayam E, Ravindar JD, Mariappan K, jiji A, Kumar M, et al. (2011) Production of Extracellular Pectinase by Bacillus Cereus Isolated From Market Solid Waste. J Bioanal Biomed 3: 070-075. doi:10.4172/1948-593X.1000046

12. Hirose N, Kishida M, Kawasaki H, Sakai T(1999) Purification and Characterization of an Endo-Polygalacturonase from a Mutant of Saccharomyces cerevisiae. Biosci Biotechnol Biochm 63:1100-1103.

13. Belarbi A, Hachet C, Helfer AC, Gognies S, Gainvors (2000) A Study of some physico-chemical characteristics of a Saccharomyces cerevisiae endopolygalacturonase: a possible use in beverage industry. J Biotechnology 24: P-296-300.

14. Asena Altan (1999) Isolation and Molecular Characterization of Extracellular Lipase and Pectinase Producing Bacteria from Olive Oil Mills. J biotechnology. 43: $67-72$.
15. Sharma DC, Satyanarayana T (2001) A marked enhancement in the production of a highly alkaline and thermostable pectinase by Bacillus pumilus dcsr1 in submerged fermentation by using statistical methods. Bioresour Technol 97 727- 733 .

16. Raj Kashyap D, Kumar Soni S, Tewari R (2003). Enhanced production of pectinase by Bacillus sp. DT7 using solid state fermentation. Bio resource technology 88: 251-254.

17. Ranveer Singh Jayani, Shivalika Saxena and Reena Gupta (1985) Microbial pectinolytic enzymes. J Biological chemistry 43: 23-31.
Submit your next manuscript and get advantages of OMICS Group submissions

Unique features:

- User friendly/feasible website-translation of your paper to 50 world's leading languages

- Audio Version of published paper

- Digital articles to share and explore

Special features:

- 100 Open Access Journals

10,000 editorial team

- 21 days rapid review process

Quality and quick editorial, review and publication processing

- Indexing at PubMed (partial), Scopus, DOAJ, EBSCO, Index Copernicus and Google Scholar etc

- Sharing Option: Social Networking Enabled

Authors, Reviewers and Editors rewarded with online Scientific Credits

- Better discount for your subsequent articles

Submit your manuscript at: www.editorialmanager.com/ibabm 